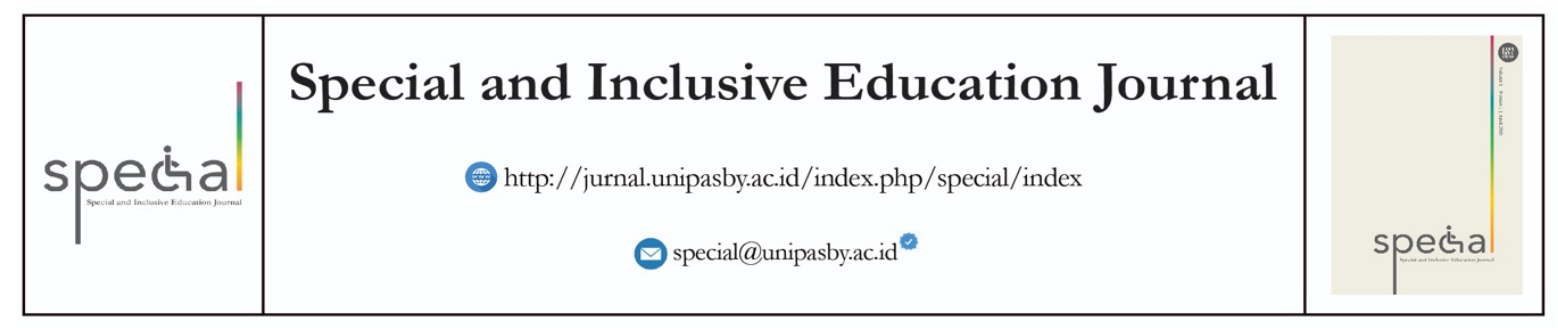

\title{
Peningkatan Kemampuan Perkalian 10-20 melalui Metode Jarimatika Pada Siswa Tunarungu di SLB-B dan Autis TPA Jember
}

\author{
Inna Hamida Zusfindhana \\ naahamida@ikipjember.ac.id \\ Pendidikan Khusus - IKIP PGRI Jember \\ Jl. Jawa No.10, Tegal Boto Lor, Sumbersari, Kec. Sumbersari, Kabupaten Jember, Jawa Timur 68121
}

\section{Artikel Info \\ Koresponden penulis : \\ Inna Hamida Zusfindhana \\ naahamida@ikipjember.ac.id}

- Diterima 13 Maret 2020

- Direview 25 Maret 2020

- Disetujui 25 Maret 2020

- Dipublikasi 29 April 2020

\section{Kata Kunci:}

Metode Jaritmatika, Siswa tunarungu, Siswa autis

\begin{abstract}
Absstrak
Tujuan dari penelitian ini untuk meningkatkan kemampuan perkalian 1020 siswa tunarunggu kelas IV. Metode yang digunakan yaitu Penelitian Tindakan Kelas (PTK) dengan tahapan para siklus, siklus 1 dan siklus 2. Subjek penelitian merupakan siswa tunarungu kelas IV yang berjumlah 5 orang. Hasil penelitian menunjukkan pada tahap pra siklus nilai yang dicapai siswa tunarungu masih belum mencapai KKM yaitu nilai 70. NA, CU mendapat nilai 40, sedangkan DN mendapat nilai 35, TA dan TE mendapat nilai 30. Pada siklus 1 nilai yang didapat oleh NA 55, CU 50, DN 60, TA 50, dan TE 55. Pada siklus II nilai yang diperoleh NA 80, CU 80, DN 85, TA 85 dan TE 80. Berdasarkan hasil nilai tes yang diperoleh dari siklus I sampai siklus II diketahui bahwa kemampuan mengenal perkalian 10-20 pada siswa tunarungu kelas IV di SLB-B dan Autis TPA Jember mengalami peningkatan
\end{abstract}

\section{Keywords:}

Jaritmatika Method, Deaf students, Autism Students

\begin{abstract}
Abstarct
The purpose of this study is to improve the multiplication ability of 10-20 grade IV students with disabilities. The method used is Classroom Action Research (CAR) with the stages of the cycle, cycle 1 and cycle 2 . The research subjects were Grade IV deaf students are 5 students. The results showed in the pre-cycle stage the value achieved by deaf students still did not reach Minimal completeness criteria which is 70 . NA, CU got 40, while DN got 35, TA and TE got 30. In cycle 1 the value obtained by NA 55, CU 50, DN 60, TA 50, and TE 55. In cycle II the values obtained were NA 80, CU 80, DN 85, TA 85 and TE 80. Based on the test results obtained from cycle I to cycle II it is known that the ability to recognize 10-20 multiplications in class IV deaf and Autism students in SLB-B in Jember have increased
\end{abstract}




\section{PENDAHULUAN}

Tunarungu adalah kondisi dimana individu mengalami hambatan dalam pendengaran. Ketunarunguan merupakan ketidakmampuan untuk mendengar disertai dengan ketidakmampuan berkomunikasi secara wajar. Gangguan pendengaran pada tunarungu berdampak utama pada perkembangan anak terutama dalam bidang bahasa dan ujaran. Gangguan pendengaran pada siswa tunarungu menyebabkan siswa kesulitan dalam mempelajari materi yang bersifat abstrak (Jauhari, M. N., Irvan, M., \& Sakre, 2018). Strategi yang tepat dalam proses belajar siswa tunarungu dapat menghasilkan pemahaman yang cepat dan benar oleh siswa tunarungu. Membangun sebuah pemahaman atau pengetahuan (constructing understanding or knowledge) merupakan konsep dasar dari pemahaman belajar, hal ini dilakukan dengan cara menyamakan kondisi fenomena, ide atau aktivitas dengan pengetahuan yang telah atau sedang dipelajari. Siswa tidak hanya sekedar menghafal atau meniru tetapi siswa juga harus membangun konsep pribadi (mind concept) dalam sudut pandangan belajar bermakna (Jauhari, M. N. (2016)

Perkembangan usia siswa SD secara kognitif adalah pada materi yang berhubungan dengan konkret. Materi yang konkret adalah materi yang dapat dipelajari dan ditangkap oleh panca indera. Tahapan pada proses pembelajaran konkret adalah tahapan konkret, semi konkret, semi abstrak dan selanjutnya abstrak. Matematika merupakan mata pelajaran yang bersifat abstrak. Pelajaran matematika memiliki banyak kegunaan dalam penerapan kehidupan sehari-hari. Mata pelajaran matematika membutuhkan strategi pembelajaran yang dapat membantu siswa dalam mempercepat pemahaman siswa terhadap materi. Materi matematika yang sedang siswa ini pelajari adalah perkalian. Materi perkalian cenderung pada menghafal. Siswa kesulitan dan kurang optimal pada penghafalan perkalian. Siswa belum mampu menghafal perkalian bilangan lebih dari 10.

Berdasarkan kondisi objektif di lapangan, dalam mata pelajaran matematika perkalian guru hanya menggunakan teknik ceramah dan menghafal. Teknik menghafal ini membuat siswa kesulitan dalam mempelajari materi perkalian. Setelah memberikan teknik ceramah dengan menggunkan bahasa isyarat lalu guru memberika soal latihan-latihan kepada siswa. Sehingga siswa tunarungu kesulitan dalam mengkal materi mengenai perkalian. Metode dan teknik pembelajaran yang menarik, menyenangkan dan tepat dapat membantu siswa dalam mempercepat menguasai perkalian. Teknik pembelajaran yang dapat digunakan oleh guru dalam memberikan materi perkalian pada siswa adalah teknik jarimatika. Teknik jarimatika ini menggunakan jari tangan dalam melakukan operasi hitung.

Menurut Sedangkan Sungatmi (2010, hlm. 1) jarimatika merupakan cara berhitung dengan menggunakan 10 jari. Jarimatika merupakan teknik pembelajaran berhitung dengan menggunakan 10 jari tangan. Jarimatika bagi orang Indonesia lebih akrab dikenal dengan maksud menggunakan jari untuk aritmatika (keterampilan berhitung) pada matematika. Kelebihan jarimatika menurut Wulandani (2011, hlm. 17) yaitu : (a) jarimatika memberikan visualisasi proses berhitung. Hal ini akan membuat anak mudah melakukannya. (b) gerakan jari-jari tangan akan menarik minat anak. Mungkin mereka menganggapnya lucu sehingga mereka akan melakukannya dengan gembira. (c) 
jarimatika tidak akan memberatkan memori otak. (d) alatnya tidak perlu dibeli, tidak akan pernah ketinggalan dimana menyimpannya, dan juga tidak dapat disita ketika sedang ujian.

\section{METODE PENELITIAN}

Penelitian ini merupakan penelitian berbasis kelas. Adanya masalah yang ditemui oleh peneliti ketika di lapangan sehingga diperlukan suatu media atau metode untuk menanganinya. Menurut Kasbolah (1999, hlm. 12) penelitian tindakan kelas merupakan penelitian yang dilakukan guna memperbaiki pembelajaran di kelas. Subjek penelitian ini adalah siswa tunarungu kelas IV yang berjumlah 5 orang. Penggumpulan data yang digunakan dalam penelitian ini adalah berupa observasi, tes, dan dokumentasi. Model penelitian tindakan kelas berupa rangkaian siklus yang terdiri dari empat tahapan penelitian yaitu perencanaan, tindakan, observasi dan refleksi. Model penelitian yang digunakan dalam penelitian ini adalah model penelitian Kemmis dan Mc Taggart (dalam Sukardi 2007, hlm. 214). Menurut Kemmis dan Mc. Taggart pelaksanaan penelitian tindakan mencakup empat langkah, yaitu: 1). merumuskan masalah dan merencanakan tindakan; 2). melaksanakan tindakan dan monitoring (pengamatan); 3). refleksi hasil pengamatan; 4). perencanaan untuk pengembangan selanjutnya.

Adapun pelaksanaan penelitian tindakan kelas dalam penelitian ini adalah :

1. Pertama, Perencanaan tindakan adalah tindakan mempersiapkan semua instrumen, sarana, dan semua yang diperlukan dalam penelitian tindakan kelas. Tahap-tahap perencanaan perlu direncanakan secara rinci untuk mendukung proses pembelajaran. Menyusun dan menyiapkan Rencana Pelaksanaan Pembelajaran (RPP) tentang materi pembelajaran yang akan dilaksanakan.

2. Kedua, tindakan akan dilakukan dalam dua siklus, dimana siklus I dan II dilakukan masing-masing 2 kali pertemuan. Pelaksanaan tindakan dalam penelitian dilaksanakan sesuai skenario pembelajaran yang telah tertuang dalam RPP. Penelitian akan dilaksanakan pada saat kegiatan belajar mengajar sedang berlangsung sampai pembelajaran berakhir.

3. Ketiga, Menurut Arikunto (2006, hlm. 229) observasi merupakan kegiatan yang tidak hanya sekedar mencatat tetapi juga mengadakan pertimbangan kemudian mengadakan penelitian ke dalam suatu skala bertingkat.

4. Keempat, Refleksi merupakan bagian yang penting dalam memahami dan memberikan makna terhadap proses dan hasil (perubahan) yang terjadi sebagai akibat adanya tindakan (intervensi) yang dilakukan (Kasbolah, 1999, hlm. 74-75). Refleksi dilakukan untuk mengetahui indikator pembelajaran yang sudah terpenuhi. Apabila masih belum mencapai indikator, maka langkah selanjutnya adalah mengulang tahapan-tahapan dalam RPP sampai siswa telah mencapai indikator yang ingin dicapai. 
Analisis data diperoleh setelah data-data dalam penelitian terkumpul dan digunakan untuk mendapatkan satu kesimpulan. Penelitian ini menggunakan teknik deskriptif kualitatif dan kuantitatif. Data kualitatif diperoleh dari lembar observasi terhadap aktifitas siswa sedangkan data kuantitatif diperoleh dari hasil tes lisan yang diberikan kepada siswa tunagrahita ringan. Analisis kuantitatif digunakan untuk menganalisis data dari instrumen tes dengan cara menghitung skor yang diperoleh siswa (Arikunto, 2015, helm. 272). Cara menghitung ketuntasan individual menggunakan rumus sebagai berikut :

$$
\text { Nilai }=\frac{\text { skor perolehan }}{\text { skor maksimal }} 100
$$

\section{HASIL DAN PEMBAHASAN}

Pada penelitian ini dilakukan 4 tahap yaitu tahap prasiklus, siklus I dan siklus II. Setiap siklus dilakukan dengan 2 kali pertemuan dalam waktu 1 jam. Kegiatan prasiklus diberikan untuk mengetahui kemampuan awal siswa tunarungu kelas IV yang berjumlah 5 orang di SLB-B dan Autis TPA Jember dalam mengenal perkalian 10-20. Setelah dilakukan observasi kemudian di lanjutkan dengan refleksi dan diketahui bahwa kemampuan mengenal perkalian 10-20 siswa tunarungu adalah sebagai berikut:

Tabel 1. Penilaian hasil observasi saat dilakukan kegiatan prasiklus

\begin{tabular}{clc}
\hline No. & Nama Siswa & Nilai \\
\hline 1. & NA & 40 \\
\hline 2. & CU & 40 \\
\hline 3. & DN & 35 \\
\hline 4. & TA & 30 \\
\hline 5. & TE & 30 \\
\hline
\end{tabular}

Berdasarkan tabel 1 hasil data tersebut menunjukkan bahwa kemampuan berhitung dalam perkalian 10-20 siswa tunarungu di SLB-B dan Autis TPA Jember masih di bawah rata-rata. Hasil ini bisa dilihat dari nilai yang dicapai siswa tunarungu masih belum mencapai KKM yaitu nilai 70 . NA, CU mendapat nilai 40, sedangkan DN mendapat nilai 35, TA dan TE mendapat nilai 30. Hal ini perlu diberikan tindakan untuk meningkatkan kemampuan berhitung dalam perkalian 10-20. Sehingga perlu diberikan solusi yang dapat meningkatkan kemampuan berhitung dalam perkalian yaitu melalui metode jarimatika.

Langkah selanjutnya yaitu observasi dilaksanakan pada saat pembelajaran berlangsung yang bertujuan untuk mengetahui peningkatan kemampuan belajar pada siswa. Pengamatan ini dilaksanakan dengan berpedoman pada lembar observasi yang telah dirancang sebelumnya. Kemampuan belajar mengenal bilangan yaitu perkalian melalui metode jarimatika menggunakan tes 
lisan yaitu menyebutkan hasil perkaliannya. Tujuan dari tes ini adalah untuk mengetahui ada atau tidaknya peningkatan kemampuan mengenal perkalian siswa tunarungu kelas IV di SLB-B dan Autis TPA Jember . Hasil tes tersebut disajikan dalam tabel berikut ini :

Tabel 2. Hasil Tes Kemampuan Perkalian 10-20 Melalui Metode Jarimatika

\begin{tabular}{clc}
\hline No. & Nama Siswa & Nilai \\
\hline 1. & NA & 55 \\
\hline 2. & CU & 50 \\
\hline 3. & DN & 60 \\
\hline 4. & TA & 50 \\
\hline 5. & TE & 55 \\
\hline
\end{tabular}

Berdasarkan tabel 2. pada siklus I nilai yang didapat oleh NA 55, CU 50, DN 60, TA 50, dan TE 55. Berdasarkan hasil tes dari penilaian di siklus I menunjukkan bahwa kemampuan perkalian 10-20 siswa tunarungu masih rendah walaupun ada sedikit peningkatan dari kegiatan prasiklus dikarenakan nilai siswa masih belum memenuhi kriteria ketuntasan minimal (KKM) yaitu 70. Hal ini disebabkan karena siswa masih kurang tertarik dan penyampaian materi masih terlalu monoton. Pada NA nilai mengalami peningkatan tapi masih di bawah KKM karena belum sepenuhnya memahami metode jarimatika, sedangkan CU kurang bisa berkonsentrasi selama proses pembelajaran. DN sudah mulai bisa menguasai perkalian 10-13. TA meskipun sudah ada peningkatan tetapi masih bingung membedakan irama jari kanan dan kiri. TE masih suka bermain sehingga tidak bisa fokus saat diberikan pertanyaan. Maka dari itu pada pelaksanaan siklus II harus dilaksanakan untuk memperbaiki kekurangan yang ada pada siklus I.

Hasil observasi pada siklus II siswa tunarungu menggunakan tes lisan menyebutkan hasil perkalian 1-200. Hasil tes tersebut disajikan dalam tabel berikut :

Tabel 3. Hasil Tes Kemampuan Mengenal Perkalian 10-20

\begin{tabular}{clc}
\hline No. & Nama Siswa & Nilai \\
\hline 1. & NA & 80 \\
\hline 2. & CU & 80 \\
\hline 3. & DN & 85 \\
\hline 4. & TA & 85 \\
\hline 5. & TE & 80 \\
\hline
\end{tabular}

Berdasarkan tabel 3. pada siklus II nilai yang diperoleh NA 80, CU 80, DN 85, TA 85 dan TE 80. Berdasarkan hasil observasi di atas menunjukkan bahwa kemampuan perkalian 5-10 pada siswa tunarungu di siklus II sudah lebih baik daripada sebelumnya. Pada siklus II, peneliti menggunakan strategi pembelajaran yang berbeda. Di siklus I peneliti menggunakan metode ceramah dan tidak interaktif dengan siswa sehingga berpengaruh pada penerimaan materi yang disampaikan pada siswa. 
Pada siklus II strategi pembelajaran dengan mengajak siswa belajar sambil bermain. Siswa tunarungu antusias ketika mengikuti proses pembelajaran sehingga materi pembelajaran yang diberikan mudah diingat oleh siswa dan nilai yang didapat juga cukup memuaskan. Kelima siswa tunarungu memeroleh nilai yang melampaui batas KKM sehingga bisa dikatakan siswa tunarungu mampu menyebutkan perkalian 10-20.

Penggunaan metode jarimatika untuk pembelajaran matematika dengan materi perkalian 10-20 pada siswa tunarungu kelas IV di SLB-B dan Autis TPA Jember bisa menciptakan suasana pembelajaran yang menyenangkan sehingga siswa tertarik dan tidak mudah bosan. Karena penggunaan metode jarimatika mampu memudahkan siswa tunarungu untuk berhitung. Penelitian tindakan dilaksanakan sebanyak II siklus. Tiap siklus terdiri atas 2 kali pertemuan yang masing-masing pertemuan berlangsung selama 1 jam pembelajaran.

Berdasarkan hasil nilai tes yang diperoleh dari siklus I sampai siklus II diketahui bahwa kemampuan mengenal perkalian 10-20 pada siswa tunarungu kelas IV di SLB-B dan Autis TPA Jember mengalami peningkatan. Hasil ini terlihat dari peningkatan nilai hasil tes yang diperoleh oleh siswa tunarungu. Siswa dapat aktif dan interaktif dalam pembelajaran pengembangan kemampuan kognitif yang menyenangkan.

\section{KESIMPULAN}

Berdasarkan hasil dan pembahasan penelitian mengenai kemampuan perkalian 10-20 siswa tunarungu kelas IV diperoleh bahwa kelima siswa tunarungu masih berada di bawah rata-rata. Sehingga untuk mengatasi hal tersebut dibutuhkan suatu metode yaitu melalui metode Jarimatika. Penelitian ini menggunakan Penelitian Tindakan Kelas (PTK) yang terdiri dari tahap para siklus, siklus 1 dan siklus 2. Pada tahap pra siklus nilai yang dicapai siswa tunarungu masih belum mencapai KKM yaitu nilai 70. NA, CU mendapat nilai 40, sedangkan DN mendapat nilai 35, TA dan TE mendapat nilai 30.

Pada siklus 1 nilai yang didapat oleh NA 55, CU 50, DN 60, TA 50, dan TE 55. Pada siklus II nilai yang diperoleh NA 80, CU 80, DN 85, TA 85 dan TE 80. Berdasarkan hasil nilai tes yang diperoleh dari siklus I sampai siklus II diketahui bahwa kemampuan mengenal perkalian 10-20 pada siswa tunarungu kelas IV di SLB-B dan Autis TPA Jember mengalami peningkatan. Hasil ini terlihat dari peningkatan nilai hasil tes yang diperoleh oleh siswa tunarungu. Siswa dapat aktif dan interaktif dalam pembelajaran pengembangan kemampuan kognitif yang menyenangkan. 


\section{DAFTAR PUSTAKA}

Sungatmi. (2010). Jarimatika: Berhitung dengan Jari. Yogyakarta: Yuma Pressindo.

Wulandani, Septipeni. (2011). Jarimatika Penambahan dan Pengurangan. Jakarta: PT. Kawan Pustaka.

Jauhari, M. N., Irvan, M., \& Sakre, T. Media Pembelajaran Signalong Indonesia Untuk Melatih Kemampuan Komunikasi ABK.

Jauhari, M. N. (2016). Identifikasi Perkembangan Komunikasi Anak Pervasive Developmental Disorder. Helper: Jurnal Bimbingan dan Konseling, 32(2).

Kasbolah, Kasihani. (1999). Penelitian Tindakan Kelas (PTK). Jakarta: Departemen Pendidikan dan Kebudayaan, Direktorat Jenderal Pendidikan Tinggi, Proyek Pendidikan Guru Sekolah Dasar.

Sukardi. (2005). Metodologi penelitian pendidikan : kompetensi dan praktiknya. Jakarta: Bumi Aksara Arikunto, S, Suhardjono, dan Supardi. (2014). Penelitian Tindakan Kelas. Jakarta: Bumi Aksara 